\title{
Chinese Mediation on the Eve of Modernization
}

\author{
Jerome Alan Cohen*
}

\begin{abstract}
It is better to die of starvation than to become a thief; it is better
\end{abstract} to be vexed to death than to bring a lawsuit.-Chinese proverb.

$\mathrm{O}$ NE OF THE MOST STRIKING ASPECTS of the legal system of the People's Republic of China is the unusual importance of mediation in the resolution of disputes. Adjudication and even arbitration are regarded as last resorts in Communist China, because those methods, by definition, terminate controversies without consent of the parties. In this article the term "mediation," which for our purposes is synonymous with "conciliation," refers to the range of methods by which third persons seek to resolve a dispute without imposing a binding decision. The Chinese mediator may merely perform the function of an errand boy who maintains contact between parties wlio refuse to talk to one another. At the other end of the spectrum, he may not only establish communication between parties, but may also define the issues, decide questions of fact, specifically recommend the terms of a reasonable settlement-perhaps even give a tentative or advisory decision-and mobilize such strong political, economic, social and moral pressures upon one or both parties as to leave little option but that of "voluntary" acquiescence."

Today's mainland Chinese faithfully follow the adinomition of Mao Tse-tung that "disputes among the people" (as distinguished from those involving enemies of the people) ought to be resolved, whenever possible, by "denrocratic methods, methods of discussion, of criticism, of persuasion and education, not by coercive, oppressive methods."2 Most civil disputes

* A.B., 1951, LL.B., 1955, Yale University; Professor of Law, Harvard Law School.

The author is grateful to the Ford Foundation, the Rockefeller Foundation, the University of California (Berkeley), and Elarvard University for supporting the research upon which this article is based.

An earlier version of this article was contributed to a symposium on "Traditional and Modern Legal Institutions in Asia and Africa," which will be published in a forthcoming special issue of the Journal of Asian and African Studies.

1 The latter illustration stretches the theoretical American definition of mediation as the process by which a third person intervenes between two contending parties in an effort to reconcile them. But that definition fails to recognize the extent to which American nediators, at least in disputes affecting the public interest, actually bring pressure on reluctant parties to accept an unsatisfactory settlement. See, e.g., Cox AND BOK, CASES ON LABOR LAW 891-98 (6th ed. 1965).

2 Address by Mao Tse-tung, "On the Correct Handling of Contradictions Among the People," Feb. 27, 1957, reprinted in 5 CHUNG-HUA JEN-MIN KUNG-HO-KUO FA-KUET HuI-PIEN [Collection of Laws and Regulations of tHe People's Republic of ChINa] $1,5-6$ (1957). 
between individuals are settled by extrajudicial mediation. ${ }^{3}$ From incomplete Chinese statistics we can infer that there are probably more than two hundred thousand semi-official "people's mediation committees" in urban and rural residential areas and that their members annually dispose of millions of disputes. ${ }^{4}$ Policenen, bureaucrats, members of the Communist Party and Communist Youth League, work supervisors, umion activists and members of other semi-official local groups undoubtedly settle an even larger number. ${ }^{5}$ A great many of those disputes that actually reach the courts end in judicially sponsored compromises. ${ }^{\circ}$ Furthermore, disputes between public enterprises, such as a state factory and an agricultural commune, are often resolved through mediation processes, ${ }^{7}$ and this appears to be almost exclusively the case with international maritime and trade disputes handled in Peking. ${ }^{8}$ There is also a

3 The Chinese have so informed foreign visitors. See, e.g., Mizuno Tōtarō, The Judicial System, in Chūgokv No Hō To Skakax [ChINese Law aNd Soctety] 51, 54 (1960). Their judicial reports repeatedly make this claim. See, e.g., Liu Hsiu-feng, Report on the Work of the Shansi [Province High] Court, Shansi Daily, Dec. 8, 1958 [hereinafter cited as Shansi Report], English translation in U.S. Consulate, Howo KoNo, SURveY of China Mannland Press [hereinafter cited as SCMP] 1946, pp. 14, 16-17 (1959); and Chu K'ai-ch'üan, Work Report on Higher Pcople's Court of Kiangsi [Province], Kiangsi Daily, June 27, 1958 [hereinafter cited as Kiangsi Report], English tranlation in SCMP 1869, pp. 27, 34 (1958). And the author's interviews with Chinese emigrees provide further impressionistic confirmation.

4 In late 1954, a time when mediation committees had not yet been established throughout the nation, it was reported that according to initial statistics there were already 155,100 such committees. On the basis of many fragmented reports of the number of cases settled by these committees it would be conservative to estimate that on an average each of them settles fifty disputes per year. See People's Mediation Organizations Develop Great Effect to Strengthen Unity and Promote Production, New China News Agency, Dec. 19, 1954, reprinted in SCMP 960, p. 23 (1955). For details concerning the structure and function of these committees, see General Rules for the Provisional Organization of People's Mediation Committees [hereinafter cited as Mediation Committee Rules], March

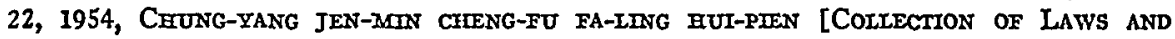
Decrees of the Centrat People's Governament] 47 (1954).

5 See, e.g., Ch'en Huai-ning, People's Policemen Who Closely Rely on the Masses, People's Daily, March 4, 1959; Wang Yï-feng, My Experience as a Secretary of a YCL Branch, China Youtr, No. 22 (1963), English translation in U.S. Consulate, Hono Kona, Selections From China Matniand Magazmnes, 401, p. 26 (1964).

6 Chinese statistics for the "great leap forward" years of 1958 and 1959 gencrally state that at least half of the civil cases that reach the courts are settled through unediation. See, e.g., Shansi Report 16-17 (over 70\%); Kiangsi Report 31 ("the grcat majority"); Wu Ch'ing-ch'eng, Hopeh Province Judicial Report, Hopch Daily, Oct. 29, 1958, English translation in U.S. JonNt PUBLication Researce Service [hereinafter cited as JPRS] 1877-N (60\%); Liu P'eng, The Work Report of the Liaoning Provincial Higher People's Court, Liaoning Daily, Dec. 22, 1959, Englisl translation in SCMP 2193, pp. 39, $42(1960)(75.9 \%)$. Again, the author's interviews with emigrees confirm this general point.

7 See, e.g., Fukushima Masao, Chinese Legal Affairs, in ChnNese LAw and Socdety, op. cit. supra note 3 , at 45 .

8 See, e.g., Fellhauer, Foreign Trade Arbitral Jurisdiction in the People's Reprublic of China, 1960 (6) Recht im Aussenhandel (Beilage zur Zeitshrift Der Aussenhandel, No. 12, 
large volume of extrajudicial mediation in minor criminal cases imvolving charges such as assault, petty theft and defamation. ${ }^{9}$

Although procedures for compromising civil and minor criminal disputes are not unknown in Western legal systems, ${ }^{10}$ the Chinese are preoccupied with "persuasion" to a point beyond that found in the West. This pervasive preference for mediation also distinguishes the Chinese Communist legal system from the Soviet system. During the past few years, as part of a broad effort to resolve civil disputes by means of a variety of innovations, Soviet authorities have encouraged increased use of both extrajudicial and judicial mediation. ${ }^{11}$ Yet a number of indicators suggest that there is still a substantial difference between the two leading Communist countries in the extent to which mediation has supplanted adjudication. There is in the Soviet Union, for example, no institutional counterpart to the "people's mediation committees," which have been called "the first hine of defense in legal work" in China. ${ }^{12}$ Conversely, while in the Soviet Union state arbitration tribunals (arbitrazh) annually decide approximately one million cases of contract disputes between

1960) [Foreign Trade Law (Supplement to the magazine Foreign Trade, No. 12, 1960)] 7-8, English translation in JPRS 8612, which states that all of the sixty-one cases of disputes between Chinese government foreign trade enterprises and capitalist business firms that had heen presented to the Foreign Trade Arbitration Commission in Peking had been settled through adjustment under the auspices of that agency; and How the Case of the M/S Varild Was Settled, Foreign Trade, October, 1963, p. 4.

${ }^{0}$ Article 3 of the Mediation Committee Rules, supra note 4, simply authorizes mediation in "minor criminal cases." Members of mediation committees are very active in various types of cases that are roughly equivalent to our misdemeanors against the person and against private property. See, e.g., Yang Tzu-wei, Report of the Work of Tsinghai Provincial Higher People's Court, Tsinghai Daily, Dec. 15, 1959, English translation in SCMP 2231, p. 31 (1960). Moreover, a variety of other official and semi-official persons perform similar functions. See Cohen, The Criminal Process in the People's Republic of China: An Introduction, 79 HARv. L. Rev. 469, 497 (1966).

${ }^{10}$ See, e.g., Biglia and Spinosa, The Function of Conciliation in Civil Procedure, 10 Irr. Soc. Scr. Burt. 604 (1958); Toussaint, Concitiation Proceedings in the Federal Republic of Germany, Switzerland, Austria, Scandinavia, England and the United States, 10 Irr. Soc. Scr. BUtL. 616 (1958); Miller, The Comprontise of Criminal Cases, 1 So. CaI. L. Rev. 1 (1927).

11 See O'Connor, Soviet Procedures in Civil Decisions: A Changing Balance Between Public and Civic Systems of Public Order, 1964 U. Irx. L. FORUM 51, 64-65, 82-84, 94-95, 99-100.

12 Yeh Ku-lin, Thoroughly Developing the Construction of Socialistic Service Is a Function of People's Mediation Work, 1964 (4) CHENG-FA YEN-CHIU [hereinafter cited as Poltitcal-Legar Research] 12, 14. The semi-official Soviet comrades' courts mediate certain categories of petty civil disputes between individuals. But they also engage in a large amount of adjudication, and their power to adjudicate undoubtedly enables them to induce agreement in many instances. Moreover, the primary purpose of these comrades' courts is not to settle private disputes but to reform those who commit minor crimes and violate socialist ethics. See generally Berman and Spindler, Soviet Comrades' Courts, 38 WASE. L. REV. 842 (1963). 
socialist enterprises, ${ }^{13}$ in China this type of agency was abolished as unnecessary a year after it was established on an experimental basis. This was not only because interenterprise contract disputes are said to be relatively rare in China, but also because most of those cases that do arise are settled through "criticism and self-criticism."14 Similarly, althougl1 many decisions of the special Soviet arbitration commissions for foreign trade and maritime disputes have developed a substantial body of law relating to international commerce, ${ }^{15}$ we have yet to learn of a single dispute before their sister institutions in China that has been disposed of by arbitration rather than mediation. ${ }^{16}$ Finally, although both Soviet and Chinese courts are legally required to attempt to effect a reconciliation before granting a divorce, that requirement has largely been treated as a formality in the Soviet Umion. ${ }^{17}$ Chinese courts, on the other hand, conscientiously observe it and appear to achieve a far higher percentage of reconciliations than Soviet courts. ${ }^{18}$ Thus, despite the fact that the tecl1miques of "criticism and self-criticism" have long been employed by the Communist Party of the Soviet Umon, the prominence of mediation in contemporary China does not appear to be attributable to importation of the Soviet political-legal model. Indeed, Chinese writers have claimed that, by emphasizing mediation, the Chinese Communist Party and its chairman, Mao Tse-tung, have engaged in the creative development of Marxist-Leninist legal doctrine. ${ }^{19}$ Soviet scholars have sliown a considerable amount of interest in Chinese mediation practices and other modes of himiting the need for judicial adjudication, ${ }^{20}$ and this Chinese expe-

13 See Loeber, Plan and Contract Performance in Soviet Law, 1964 U. ILx. L. Foruar $128,133$.

14 Fukushima Masao, supra note 7, at 45.

${ }^{15}$ See Pisar, Soviet Conflict of Laws in International Commercial Transactions, 70 Harv. L. Rev. 593, 607 (1957).

16 See note 8 supra.

17 See, e.g., FETFER, Justice IN Moscow 163-77 (1964); Juviler, Marriage and Divorce, Survey, No. 48, July, 1963, pp. 104, 106-07, 111-12.

18 For representative accounts of the reconciliation efforts of Chinese courts, see, e.g., Greene, Awakened China 199-209 (1961); Chome, Two Trials in the People's Reprublic of China, LAw IN THe Service of PeAce, New Series 4, June 1956, pp. 102-05. Juviler, supra note 17, at 107 , states that Soviet "couples rarely are [reconciled], according to overwhelming testimony" and that the highest percentage of reconciliations about which he read was 4 per cent in the Kazakh republic for 1957. In China divorce cases constitute over half the number of civil cases, Mizuno Tōtarō, subra note 3, at 54; and, as indicated in note 6 supra, a very high percentage of civil cases are disposed of through settlement.

10 See, e.g., Yeh Ku-lin, supra note 12 , at 12 .

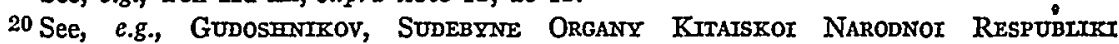
[Legai Organs of the People's Repudic of China] (1957), English transiation in JPRS 1698-N (1959) especially pp. 16-17, 45, 71-73 of the latter; Ostroumov, The New Form of Involvement of the Community in the Struggle for Conformity to Rules of Socialist Community Life in the [Chinese People's Republic], SOVETSKove cosudarstvo I pravo [Soviet State aNd Law], No. 5, p. 73 (1960). 
rience may well have stimulated and influenced the recent Soviet procedural innovations. ${ }^{21}$

How then can we explain this Chinese Communist phenomenon? The foreign observer is tempted to attribute it to what he suspects must be the inevitable impact, even upon radical revolutionaries, of millennial Confucian culture. He may find apparent support in contemporary Chinese assertions that mediation is "one of China's fine traditions."22 These assertions, however, do not imply simple Communist adoption of the mediation practices that prevailed either under the predecessor regimethe Republic of China-or under the last of the imperial dynasties that ruled China for over two thousand years-the Ch'ing or Manchu dynasty (1644-1912). Such a confession of continuity would be inconsistent with the Party line on law, which has sought to discredit both the imperial and the Republican legal systems as exploiters of the masses and has emphatically rejected arguments that favor the "inheritability" of "the old law."23 The tradition to which the Communists ordinarily refer is that established during their two decades of control over revolutionary bases in remote "liberated areas" of China prior to their assumption of national power in 1949. It has been claimed, for example, that the mediation system developed in the liberated areas (which by 1945 liad a total population of roughly ninety million) was fundamentally different from its nonCommumist predecessors, since under earher regimes the wealthy and influential classes corruptly manipulated mediation to evade the law and to oppress the toiling classes. ${ }^{24}$ To the extent that Communist mediation is related to China's "semi-feudal" past, it is said to be linked not to the mediation practices foisted upon the masses by the dominant landlords and the important bourgeoisie, and the local bosses and "bad gentry" who served them, but to "the long and excellent tradition of eliminating difficulties and resolving disputes" that the masses themselves developed during the centuries that they remained in an exploited, enslaved status. ${ }^{25}$

Adequate evaluation of this Communist interpretation requires examination of the theory and practice of Ch'ing mediation in the late nineteenth

21 This view is supported by a Western authority on Soviet law who has studied these innovations. See O'Connor, supra note 11, at 84, 94-95, 98 n.206, 101.

22 See, e.g., Is It Necessary for Us to Retain the People's Mediation Committees?, Kuang Ming Daily, Sept. 2, 1956, English translation in SCMP 1391, pp. 7, 9 (1956).

${ }^{23}$ See, e.g., Shih Huai-pi, A Critique of the Reactionary Civil Law of the Nationalist Party, 1957 (6) Political-Legal Researce 50, 54.

24 See, e.g., Ma Hsi-wu, The People's Judicial Work in the Shensi-Kansu-Ninghsia Border Area During the Stage of the New Democratic Revolution, 1955 (1) PoumucaILEGAL RESEARCH 7, 12-13.

25 Wang Min, The Major Significance of the People's Adjustment Work in Resolving Contradictions Among the People, 1960 (2) Pourticat-Legal ResearcH 27-28. 
century, just prior to the time when the impact of the West began to stimulate the transformation of the traditional legal system. It also calls for study of Republican efforts to modernize the Ch'ing system, of Communist experiments in the various liberated areas, and of Communist organization of mediation on a nationwide basis following the establishment of the People's Republic in 1949. Inasmuch as the Republic of China has continued to exist on Formosa since 1949, research into developments there should be instructive to suggest a contemporary Chinese alternative to the present Communist system. Furthermore, an important comparative perspective can be obtained by studying modernization of the traditional mediation processes of Japan, a country whose legal system has been profoundly affected by Confucian thought and values. ${ }^{28}$ An evaluation of these dimensions cannot be undertaken within the confines of a single essay. With appropriate Chinese modesty, this article may be said to represent what Chairman Mao might call the first leg of a 10,000mile march. With the aid of recent scholarship it will attempt to summarize the fragmentary evidence that we have concerning traditional Chinese mediation as it existed on the eve of twentieth century modernization.

\section{I}

\section{CONFUCIAN PREFERENCE FOR MEDIATION}

Before describing the law and practice of late Ch'ing mediation, a word should be said about the Confucian view of dispute resolution. It is difficult to define with precision the practical impact of any society's philosophical behiefs. Yet it seems clear that during the nimeteenth century Confucianism, which remained the dominant Chinese philosophy, significantly influenced the attitudes of China's rulers and, perhaps to a lesser extent, the attitudes of the populace.

According to Confucianists, the legal process was not one of the highest achievements of Chinese civilization but was, rather, a regrettable necessity. ${ }^{27}$ Indeed, it was usually considered disreputable to become involved in the law courts, even as a party with a legitimate grievance. ${ }^{28}$

26 See generally Henderson, Conctitation and Japanese Law, ToKUgawa aNd MODERN (1965).

27 For discussion of traditional Chinese conceptions of law and the dominance attained by the Confucian school, see, e.g., Cr' $\ddot{0}$, LAw aNd Soctety in Tradimtonat Cruna 226-79 (1961) [hereinafter cited as Ch'ü]; Escarra, Le Drorr Chrovors, 9-119 (Browne translation 1961) [hereinafter cited as Escarra]; Schwartz, On Attitudes Tozvard Law in China, in GovernMent UNDER LAw aNd THE INDTriduar 27 (1957); Bodde, Basic Concepts of Chinese Law: The Genesis and Evolution of Legal Thought in Tradilional China, 107 Proceedings of the Amertcan Phrlosophtcal Soctety 375 (1963).

28 During the Ch'ing dynasty Chinese law did not generally distinguish between civil and criminal litigation but basically employed the same procedure in all cases. 
A lawsuit symbolized disruption of the natural harmony that was thought to exist in liuman affairs. Law was backed by coercion, and therefore tainted in the eyes of Confucianists. Their view was that the optimum resolution of most disputes was to be achieved not by the exercise of sovereign force but by moral persuasion. Moreover, litigation led to hitigiousness and to sliameless concern for one's own interest to the detriment of the interests of society.

Confucian values emphasized not the rights of the individual but the functioning of the social order, the maintenance of the group. "[I]deas of order, responsibility, hierarchy and harmony"29 were enshrined in the prevailing social norms, the $l i$, whicli were approved patterns of behavior prescribed in accordance with one's status and the particular social context. ${ }^{30}$ Harmony was pre-eminent annong these ideas. Once it had been disturbed it could best be restored through compromise. If one felt he liad been wronged, the Confucian ethic tauglit that it was better to "suffer a little" and smooth the matter over rather than make a fuss over it and create further dissension. If one was recognized as being clearly in the right in a dispute, it was better to be inerciful to the offending party and set an example of the kind of cooperation that fostered group solidarity rather than exact one's pound of flesl and further alienate the offender from the group. As Jean Escarra lias written: "To take advantage of one's position, to invoke one's 'riglits,' has always been looked at askance in China. The great art is to give way (jang) on certain points, and thus accunulate an invisible fund of merit whereby one can later obtain advantages in other directions." 31

This attitude toward dispute settlement reflected the spirit of selfcriticism that Confucian ideology souglit to inculcate. When the model Confucian gentleman was treated by another in an unreasonable manner, he was supposed to attribute the difficulty to his own personal failings and to examine his own behavior to find the source of the problem. It was expected that by improving his own conduct he would evoke a positive response from the other party and thereby put an end to the matter. ${ }^{32}$ Moral men did not insist on their "rights" or on the exclusive correctness

There were, however, certain modifications for handling types of cases that would today be classified as "civil" in most countries, including both the People's Republic of China and the Republic of China. For discussion of some of these modifications, see CH'Ü, LOCAI

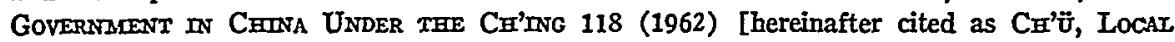
GOVERNMENT].

29 The quotation is from a translation by Joseph Needham of an excerpt from EsCARRA

17. 2 Needram, Science and Civilization in China 529 (1956).

30 CH'ü 230-31.

31 ESCARRA 17.

32 See 2 Legge, The Chinese Classics 333-34 (1960). 
of their own position, but seitled a dispute through mutual concessions that permitted each to save "face." A lawsuit caused one to lose "face" since it imphed either some falling from virtue on one's own part through obstinacy or lack of moderation or, what was also embarrassing, the failure to elicit an appropriate concession from another as a matter of respect for one's own "face." Thus, Confucianism highly prized the art of compromise and, with it, the role of the persuasive intermediary.

Another relevant facet of Confucianism was its emphasis upon preserving status differences in a hierarchically organized society. "[T]he li prescribed sharply differmg patterns of behavior according to a person's age and rank both within his family and in society at large (one pattern when acting toward a superior, another toward an inferior, still a third toward an equal)."133 Modern Western societies seek to impose universalistic, impersonal standards in order to promote democratic values and to facilitate a high degree of predictability for the consequences of conduct before the conduct has occurred. This Western attitude is usually contrasted with the highly particularistic Confucian perspective of human activity. ${ }^{34}$ In interpreting the significance of this particularisin some scholars of traditional Chinese law have claimed that "abstract ideas, concepts disentangled from facts, are almost strangers to the guiding principles of Chinese mentality" and that the Chinese attached singular weight to personal relations and to the special circumstances of each case. $^{35}$ This characterization appears to be exaggerated. Benjamin Schwartz has pointed out that there was really something impersonal about the Confucian ethic, since it required personal relations to be conducted according to norms ( $l i$ ) prescribed by social roles and apphicable to all individuals who played those roles. ${ }^{36}$ Yet, as he recognizes, the categories of social relationships were exceedingly diverse and the norms that governed the behavior appropriate to each category were based on one's position in an elaborate social hierarchy. These norms were, therefore, enormously varied. This required the participants in society to pay a good deal of attention to the precise social setting in which a dispute occurred and to search for a solution that would be consistent with the

33 Bodde, supra note 27 , at 383 . This proved to be the crucial distinction between the Confucianists and their early rivals, the Legalists, who had sought to impose legal rules that were uniformly applicable to all persons without regard to differences in social or economic status. $\mathrm{CH}^{2} \ddot{\mathrm{u}}$ 226-79, especially 274.

34 See, e.g., L. S. Yang, The Conception of Pao as a Basis for Social Relations in China, in CHINESE Thodght AND Institumons 291, 303, 307 (Fairbank ed. 1957); Parsons, The Structure of Soctal Action 550-51 (1949). Cf. von Mehren, Some Reflections on Japanese Law, 71 HARv. L. Rev. 1486, 1496 (1958).

35 See, e.g., Escarra 88, 94.

36 Schwartz, supra note 27 , at 29-30. 
respective social roles of the parties and with both their past and their future relations. In these circumstances the possibilities for flexible solutions inherent in mediation were naturally found to be congenial. ${ }^{37}$

II

\section{CH'ING LEGISLATION AND JUDICIAI PRACTICE}

One would expect the laws of traditional China to reflect this predilection for mediation. The laws of the Tokugawa Shogunate in Japan (16031868) make clear the importance of mediation in that society, which shared the Confucian heritage. Indeed, they institutionalized, and thereby reinforced, the marked preference for conpromise. Tokugawa legislation required, for example, that civil disputes be submitted to the village headman for mediation, and such an attempt at settlement was made a prerequisite to resort to the courts..$^{38} \mathrm{We}$ find no analogous emphasis upon mediation in the legislation of the Ch'ing dynasty. It is true that there was tucked away in the Official Commentary to the Ch'ing Code ( $t a$ ch'ing lii li) a provision inherited from the Ming dynasty (1368-1644) that authorized certain rural leaders and elders (li-lao) to reconcile the parties to disputes over "petty matters" sucl as those relating to domestic relations and real property. ${ }^{39}$ But all other disputes were beyond the legal competence of the local leaders and elders and were required to be brought to the county (hsien or chou) magistrate, who served as both trial judge of general jurisdiction and the national government's principal administrative officer in the area. Moreover, even the parties to a petty dispute were not legally bound to seek local reconciliation before going to court..$^{40}$ And, regardless of the nature of the dispute, once it had been brought to the attention of the magistrate, the Code precluded the local leaders from disposing of it and prohibited private settlement of any kind. ${ }^{41}$ The magistrate was permitted to authorize local leaders to investi-

37 For a different and more elaborate summary of the relation between Confucianism and mediation, see Northrop, The Mediational Approval Theory of Law in American Legal Realism, 44 VA. L. Rev. 347 (1958).

38 HENDERSON, op. cit. supra note 26, at 128-29. The vast majority of disputes were settled extrajudicially at the local level. $I d$. at 128. Moreover, Tokugawa policy and judicial practice made mediation the central principle of procedure for handling disputes that reached the courts. $I d$. at $106,127,147$.

39 See the Official Commentary to ch'e-hui shen-ming-t'ing [Destroying a Pavilion for Proclamations] in Chapter 34, hsing-lii tsa-fan [Criminal Law: Miscellaneous Offenses], ta-ch'ing lï-hi [hereinafter cited as Ch'ing Code] (Tao Kuang 2d year ed. [1822]).

40 See Cr'Ü, Local GoverNament 272 n.1.

11 See Special Provision (li) Number 8 under kao-chuang pu-shou-li [Failure to Receive and Act Upon an Accusation] in Chapter 30, hsing-lii su-sung [Criminal Law: Procedure], Ch'ing Code (Tao Kuang 2d year ed. [1822]); and Official Commentary to ssu-ho kungshih [Private Settlements Concerning Public Matters] in Chapter 34, supra note 39. 
gate and report to him about petty matters, but he himself was obligated to hear and to decide all disputes that had been presented to him and was subject to punishment for any failure to do so. ${ }^{42}$ It was not until the Ch'ing dynasty's last days, when a belated effort to modernize the regime stimulated a law reform movement, that the prohibition against local settlement of disputes which had already been presented to the magistrate was deleted from the Code. ${ }^{43}$ Thus, prior to the commencement of the legal modernization process im the formal contemplation of Ch'mg law, mediation was not an important method of resolving disputes.

The scattered evidence of judicial practice during the late $\mathrm{Ch}^{\prime}$ ing dynasty suggests that the law in action provided a more accurate index of the Chinese predisposition to compromise. Despite the statutory prohibition, mediation by influential members of the community, by neighbors of the hitigants or by a member of the magistrate's staff often settled quarrels even after a complaint had been brought to the magistrate's yamen (government office). ${ }^{44}$ It has been reported, for example, that in one village there had not been a lawsuit for more than a generation because of the restraining influence of a leading citizen who had a position in the yamen and therefore could deal with disputes before a complaint was formally heard..$^{45}$ Magistrates themselves favored extrajudicial adjustments and sometimes referred cases to appropriate non-governmental mediators. ${ }^{46}$ When such outside mediation failed and the matter went before the magistrate, the case of the party who was deemed to be obstinate was gravely prejudiced.77 Also, in cases that today would be denominated as "civil," the first thing that the magistrate had to do upon receipt

42 See Special Provision (li) Number 8, supra note 41 ; and CH'̈̈, Locax Government 203 n.14.

43 See kao-chuang pu-shou-li [Failure to Receive and Act Upon an Accusation] in su-sung [Procedure], ta-ch'ing hsien-hsing hsing-lii [The Contemporary Criminal Code of the Ch'ing] (Hsüan-t'ung 2d year [1910]). The reasons for the deletion were suggested by the principal architect of this law reform effort, Shen Chia-pen, and his collaborator, Yï Lien-san. They wrote: "The disputes involved in the accusations listed in this special provision relate only to petty civil inatters. They are unlike cases of homicide or robbery. If there are just and impartial gentry in the area [where disputes occur], it will not be inappropriate to let them adjust such disputes.

"We are afraid that the requirement that government officials must adjudicate all such disputes themselves will result in increased hitigation and that legal proceedings will thereby be delayed."

See 32 hsiuan-t'ung ta-ch'ing hsien-hsing lü an-yü [A Commentary on Provisions in the Hsịan-t'ung edition of the Contemporary Code of the Cli'ing] pp. 16, 22 (1909).

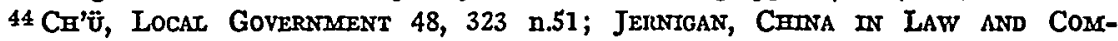
MERCE 189 (1905) [hereinafter cited as JERNIGAN].

45 Smith, Chinese Characterustics 225 (1894) [hereinafter cited as SMmth].

46 See, e.g., Hu, The Common Descent Group in Caina and Its Functions 123 (1948) [hereinafter cited as Hu] ; JeRNIGAN 189.

47 Jernigan 189. 
of a complaint was to determine by means of interrogation whether to accept or reject it. He usually made this determination with the assistance of a private secretary who was learned in the law. This determination was embodied in an official opinion that was inscribed at the end of the complaint. If the complaimt was accepted, an investigation of the merits might be ordered or the case would be set down for hearing. If the complaint was rejected, the reasons for the rejection had to be stated in the official opinion. In either event a good opinion contained an analysis of the law and the facts and could do much to persuade a plaintiff whose complaint had been rejected not to appeal to a superior court or to persuade parties whose case was scheduled for trial to settle the matter on the basis of the information set forth in the opinion. ${ }^{48}$ Compromises were also concluded during the trial and even in the course of appellate proceedings. ${ }^{49}$ Sometines a magistrate would refer a case to outside mediators if he had been unable to reach a settlement during the trial..$^{\text {50 }}$ Many judgments actually were compromise decisions, ${ }^{51}$ and it was not uncommon for a compromise to be achieved in lieu of levying execution on a judgment..$^{52}$

One should not exaggerate the role of the courts in disposing of disputes, and therefore the relative inportance of compromises achieved in the course of litigation. Thus far research has failed to unearth court statistics concerning the proportion of litigated cases that ended in either extrajudicial or judicial compromise at any given time. Moreover, because field work in the sociology of law is an innovation even today, and was unknown in nineteenth-century China, we have no reliable statistics concerning the extent to which the courts displaced informal institutions in the processes of dispute resolution. Sybille Van der Sprenkel's recent study of Ch'ing legal institutions concludes that "to adopt the course of going to law was exceptional in China,, ${ }^{, 53}$ and that, generally, one became involved im the legal system only when a problem could not be tolerably solved by other means. ${ }^{54}$ Cl' $\ddot{u}$ Tung-tsu cautions against assigning an insignificant role to the official Ch'ing legal machinery. His view is that "litigation was not uncommon." Yet he agrees that "a large area of life

48 Cम'Ü, LOCAI GOVERNMENT 99, 118.

49 See, e.g., LIN, The GoLden WING 219-20 (1948) [hereinafter cited as Lin]; Sarrtr, VIriage LAFE IN ChINA 283-86, 302 (1899) [hereinafter cited as SMITH, VIILAGE LIFE].

bo SAITH, VILIAGE LIFE 284.

51 Sartre 17; SMTth, Vinlage LIFE 178.

62 Cf. S. F. Liu, Westernized Administration of Justice and Chinese Racial Characteristics 2 (a mimeographed pamphlet translated by Alfred Wang).

53 Van der SpRenkes, Legal Instrtutions IN Manchu China 79 (1962) [hereinafter cited as VAN DER SPRENKEI].

54 ld. at 78. 
in China was regulated by ... unofficial organizations or by unwritten customs" and that "people preferred [extrajudicial] mediation to litigation. 355

This preference for extrajudicial mediation reflected more than Chinese philosophical predispositions. It was firmly grounded in practical considerations that led to what one observer of nmeteenth-century China termed "the universal dread among the people of coming before courts, and having anything to do with their magistrates. ${ }^{256}$ The court of first instance-the magistrate's yamen-was usually situated in the county seat, far from many of the villages in which the bulk of China's population resided. The time required to travel to the county seat and the expense involved in staying there were alone enough to make hitigation mfeasible for most people who did not hive nearby. ${ }^{57}$ For those who had sufficient leisure and wealth to permit a journey to the county seat and for those who lived in its vicinity there were other reasons for avoiding hitigation. Although some magistrates were known to be conscientious and able persons, many failed to inspire public confidence because they were thought to be corrupt, cruel, lazy and given to following "their own unpredictable emotions." by which a magistrate may decide a case, nine are unknown to the public."369

Even the virtuous magistrate was severely himited in carrying out his judicial functions. Although required to have a minimum knowledge of law by the time he assumed office, the magistrate was not a professional, law-trained judge, but a man who had qualified for a career in the bureaucracy by having demonstrated a mastery of the Confucian classics. As the government's principal official in the county, he was responsible for everything that went on in a large area that might have a population of several hundred thousand..$^{80}$ He had to handle the protection of public order, the entire process of the administration of justice, including the detection and apprehension as well as the adjudication and punishment of criminals, the collection of taxes, the registration of the population, the administration of public works and welfare activities, the promotion of education and culture, the leadership of public ceremonies and a variety

55 Ch'ü, Book Review, 35 Pactric Aframs 396-97 (1962-63).

561 Wuitams, THe Mmdie Kingdom 507 (1883) [hereinafter cited as Wifriass]. 67 VAN DER SPRENKET 122.

68 See H. C. W. Liv, The Traditionar Cemnese Ctan Rules 155 (1959) [hereinafter cited as Lro]; see also 1 Doolitire, Soctat LIfE of the Chinese 327, 2 id. at 161 (1867) [hereinafter cited as DoourrTIE].

${ }^{59}$ Scarborodgr, A Collection of Chinese Proverbs 335 (revised by C. W. Allen 1926) [hereinafter cited as SCARBOROUGH], quoted in VAN DER SPRENKEI. 135.

60 Chang, The Chrnese Gentry 53 (1955) [hereinafter cited as Chang]. 
of other duties. Moreover, because he was forbidden by law from being a native of the territory that he administered and because his term of office there was frequently only one or two years, he often did not know the dialect or customs of the area. ${ }^{61}$

In these circumstances the magistrate necessarily depended upon a large staff of assistants, clerks, runners, private secretaries and personal servants, and their reputation for greed, corruption and insolence was legendary and frequently well-deserved. In addition to collecting the "customary fees" that many of them felt free to demand at virtually every stage of the legal proceedings, ${ }^{62}$ these subordinates usually saw to it that no litigant could move his case through the magistrate's yamen without being subjected to a variety of unlawful practices that added appreciably to the expense of litigation..$^{63}$ The subordinates were often described as "tigers or wolves" the subject of many proverbs such as "official underhings see money as a fly sees blood" and "you pour wine and put meat into the leather bag [of the underlings] but the suit is still before the court." ${ }^{306}$ As this last proverb suggests, lawsuits tended to drag on. Another common saying was "The magistrates may go but the officers [yamen clerks] remain: the officers may go but the law-case remains. ${ }^{267}$ It is hardly surprising;

61 Id. at 53-54; 1 Doolitrue 322.

02 Customary fees, it has been pointed out, "were as numerous as the hairs on an ox." CH'Ü, LOCAL GOVERNMENT 49. "Various fees were collected from persons involved in a law suit. To begin with, there were fees for registration (kua-hao fei) and for handling a complaint ( $c h$ 'wan-ch'eng fei). Then the plaintiff had to pay a fee for getting a $p$ ' $i$, the official statement of the acceptance or rejection of a complaint (mai-p'i fei). As the usual procedure in opening a case called for such an official statement at the end of the complaint as an endorsement of the case, and it took many days to write a $p^{\prime} i$ after a complaint had been handed in, clerks and runners could take advantage of the situation and ask the plaintiff to pay some money to hasten the writing of the statement. In addition there were fees to clerks for preparing the list of people involved in a case (sung-kao chih-pi fei or $k$ 'ai-tan fei) and fees for the issuance of a warrant ( $c h^{\prime} u$ - $p^{\prime}$ iao fei). Fees collected from both plaintiff and defendant included fees for their arrival at the yamen for a trial (tao-an fei or tai-an $f e i$ ), and fees to clerks and runners for attending the court when the magistrate opened the trial ( $p^{\prime} u$-t'ang fei or $p^{\prime} u$-pan $f e i$ ). Both parties had to pay fees for expenses incurred by a magistrate and his personnel in making on-the-spot investigations (as in a law suit involving a dispute over property boundaries [ $t^{\prime} a-k$ 'an fei]), for the conclusion of a law suit (chieh-ans fei), and for the withdrawal of a law suit when an amicable agreement had been reached between the plaintiff and the defendant (ho-hsi fei). Persons involved in homicide cases were required to provide food and traveling expenses for clerks and runners, stationery expenses, oil and candle fees, and many other kinds of fees in connection with an inquest (ming-an chien-yen fei)." Id. at 47-48 (footnotes omitted).

$03 \mathrm{Ch}$ 'ü impressively documents this discouraging picture of Ch'ing justice. See, e.g., id. at $49-50,88-90,114$.

64 See Lru 155.

651 WrITIAMS 442.

66 Scarborodgr 343-44, quoted in VAN DER SpRENEet 135.

07 Scarborotgr 335, quoted in VAN DER SPRENkET 135. 
therefore, that even parties who eventually were vindicated found litigation a most uneconomical means of obtaining satisfaction. "Win your lawsuit and lose your money"68 was an aphorism born of experience. Or, as an eighteenth-century imperial edict put it, "before a legal case is tried and concluded the plaintiff and the defendant lave spent a large sum of money, so that both of them are in great distress. ${ }^{200}$ Litigation brought some people and their families to the brink of insolvency. ${ }^{70}$ Because of this, involving an enemy in a lawsuit was recognized as an effective method of gaming revenge. ${ }^{71}$

In addition to being inordinately expensive, time-consuming and unpredictable in outcome, resort to the magistrate often proved to be a degrading and harsh experience. For all but the shameless, litigation constituted public admission of some personal failing and involved the distasteful process of revealing private problems to unknown third persons. ${ }^{72}$ Moreover, those who went to court often suffered humiliation at the hands of members of the magistrate's staff who were their social inferiors. "Wherever one enters the government office, petty clerks will push him around and extort money from him. Day and night, he has to stay there to wait on their pleasure." ${ }^{\prime 33}$ Pending trial and during the long period that the case might be on appeal one. or nore of the litigants were soinetimes illegally incarcerated. ${ }^{74}$ While confined, they were subject to illegal torture and privations, and relief could only be obtained by yielding to the financial exactions of their jailers. ${ }^{75}$ At the trial the parties and witnesses were flanked by gnards wielding bamboo staves and other instruments and were required to remain in a kneeling position on the ground before the magistrate's high bench. ${ }^{78}$ No professional advocates were allowed to represent them. Occasionally, in order to elicit evidence, legally prescribed torture was administered in court. ${ }^{77}$ Furthermore, when a plaintiff was successful in obtaining a favorable decision, he often found that the remedies provided by law were too limited to grant him effective relief or were only available in theory because of the need to rely on the magistrate's staff for implementation..$^{78}$ Finally, of course, as a result of hitigation, relations between the disputants and their respective

\footnotetext{
68 SCARBOROUGH 334, quoted in VAN DER SPRENKEI 135.

69 Quoted in CH'ن̈, Local Goveranatent 50.

70 LiU 155-56; SMITH, VIILAGe LIFE 319.

711 Williaris 479; VAN DER SPJzeNkel 123.

72 See Fried, Fabric of ChInese Sochety 210 (1953) [hereinafter cited as Frmed.

73 LIU 155.

741 WIILIAMS 514-15; LIN 28-32.

751 Williars 514-15; Sagrth, VIllage Life 319.

76 CH'̈̈, Local Governacent 125; VAN der SPRENkex 69.

77 Ch'̈̈, Local Government 80, 125; Van der Spreankel 68; 1 Wintiams 507.

78 VAN DER SPRENKEL 76.
} 
families, and frequently even their clans, neighborhoods, villages or guilds, were embittered for years to come. ${ }^{79}$ In the light of all these considerations one can well understand the traditional counsel: "Let householders avoid litigation; for once go to law and there is nothing but trouble."80

Although the corruption and abuses of the judicial system were in violation of the laws, the Cli'ing emperors do not appear to have been unduly concerned by the fact that the courts were unattractive agencies for settling disputes. Except for an attempt in the 1860's to eliminate the system's worst abuses, as part of a short-lived effort to revive a regime on the verge of collapse, ${ }^{81}$ an attitude of imperial indifference to the administration of justice prevailed down to the last days of the nineteenth century. Perhaps the best known expression of the philosophy that underlay the imperial attitude toward litigation is this statement of the $K$ 'anghsi Emperor, whose lengthy reign (1662-1722) profoundly influenced the dynasty's development:

... lawsuits would tend to increase to a frightful amount, if people were not afraid of the tribunals, and if they felt confident of always finding in them ready and perfect justice. As man is apt to delude himself concerning his own interests, contests would then be interminable, and the half of the Empire would not suffice to settle the lawsuits of the other half. I desire, therefore, that those who have recourse to the tribunals should be treated without any pity, and in such a manner that they shall be disgusted with law, and tremble to appear before a magistrate. ${ }^{82}$

The good subjects, the Emperor said, would settle any difficulties between them "like brothers" by referring them to an elder or the head of their community. "As for those who are troublesome, obstinate and quarrelsome, let them be ruined in the law-courts-that is the justice that is due to them."

\section{III}

\section{EXTRAJUDICIAL MEDIATION}

Whether we characterize resort to litigation during the Ch'ing dynasty as "exceptional" or "not uncommon," it seems safe to say that, in

79 See, e.g., LrU 156; SMITH 224-25.

${ }^{80}$ Scarborotger 334, quoted in VAN Der Sprenteet 135. "This proceeding [a lawsuit] in Western lands is generally injudicious, but in China it is sheer madness. There is sound sense in the proverb which praises the man who will suffer himself to be imposed upon to the death before he will go to the law, which will often be worse than death." Surrr 224-25.

81 Wriger, The Last Stand of Chinese Conservatisa 139-41 (1957).

82 JERNIGAN 191.

83 Id. at 191-92.

84 Compare text accompanying note 53 sufra with text accompanying note 55 supra. 
keeping with the K'ang-hsi Emperor's admonition, most disputes were disposed of outside the formal legal system. Apart from the use of force and self-help, the processes of dispute resolution einployed by local groups such as the clan, the guild and the village ranged from informal mediation to public adjudication. The limited anıunt of relevant documentation that we possess suggests that in most instances disputes were resolved by informal mediation.

Informal mediation might in practice begin by one of the parties to a dispute calling on a third person, either in virtue of friendship or other personal relationship or because he lad served as middleman or witness in the transaction which had given rise to the difficulty, to try to persuade the other party to fulfill his obligations. Or, a third person, knowing of an imcipient quarrel, might offer his services as mediator, in the loope of winning some return for his help, or because he felt some duty to keep kinsman or friend out of trouble. ${ }^{85}$

Unofficial "peace-talkers" were said to be ubiquitous in nineteenth-century China, and nuch of the responsibility for maintaining order devolved upon them. ${ }^{86}$ Generally, it was only when such informal mediation failed that inore formal intervention of the local group took place, and even then great emplasis was placed on persuading rather than forcing the parties to conclude the matter. In view of the diversity of Chinese practice, perhaps the best way to illustrate the scope of mediation is to suggest some of the principal methods of adjustment employed by each of the inajor umits of traditional Chinese society.

\section{A. Disputes Within the Family}

Quarrels within the family were frequently decided by the head of the family, who was either the father or grandfather, depending on the size of the family unit that lived together ${ }^{87}$ His authority was said to be absolute. ${ }^{88}$ Yet in practice there was undoubtedly a good deal of mediation within the household, as when parents sought to reconcile disputes between sons or between an unmarried daughter and the wife of a son. Mediation was more apparent when conducted by persons who hed outside the household. This often occurred, for example, at the time of the dissolution of the family into smaller units and the accompanying division of the family property. In such cases the outside niediator was norinally a senior disinterested person who enjoyed the confidence of the family, such as a maternal uncle, ${ }^{89}$ an elder within the circle of mourning

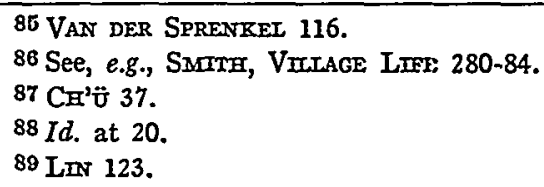


relatives, ${ }^{90}$ the head of the clan or of the clan subdivision, or some other recognized community leader. ${ }^{91}$ Outside mediation was also common when a mother-in-law's mistreatment of her daughter-in-law became excessive. Other kinds of family disputes could also elicit outside intervention, either by relatives, friends or neighbors or by the leaders of the community. ${ }^{92}$ The services of sucl outside mediators were not always requested, but were imevitable once a disturbance became known. As one observer of late mineteenth-century Chinese life put it, village elders "do not scruple to enter on the scenes of family broils, and to constitute themselves judges of the matters in dispute." $" 93$

The outside mediator would allow each party to the dispute an adequate opportunity to express his grievances. He would then formulate a proposal for adjusting the controversy in the light of local customs, Confucian social norms $(l i)$, clan rules and perhaps the official laws and policies. The weight that his proposal carried usually varied in direct proportion to its reasonableness and to his prestige among the family. On some occasions the proposal would be promptly accepted by the disputants. At other times it would constitute a basis for further bargaining, and after protracted efforts the mediator usually could bring to bear sufficient moral or social pressure to cause the parties to compromise their differences in some mutually tolerable fashion. In certain kinds of disputes the mediator supervised the drawing of lots to settle the matter. ${ }^{94}$ In many other instances he tended to make negotiated decisions. ${ }^{95}$

\section{B. Disputes Within the Clan}

In those areas of China where organizations based on common descent were strong, disputes between members of the same hineage group or clan were usually solved within that group. Clan rules generally required all such disputes, other than those involving serious crimes, to be submitted for settlement within the clan. If a clan member attempted to bypass the clan by going directly to the magistrate, even though he may have had a good case on the merits, ${ }^{96}$ he was subject to punishment by the clan "for having forgotten that the other party who has wronged him is a fellow clan member and a descendant froin the same origin. ${ }^{.97}$ It was the goal of

$90 \mathrm{HU}$ I7; 2 DooLTrTe 225.

012 Dooritrie 119.

92 For an extremely amusing caricature of Chinese mediation in action, see SMrTH, VIILAGE LIFE 277-78.

93 Dougras, Soctety in Carna 112 (1894) [hereinafter cited as Douglas].

$04 \mathrm{HU} 119$.

85 For an illustration of this process, see $\operatorname{LnN} 123-25$.

96 Lro 156-57; see also Hu.

97 LIT 157. 
each clan to handle its own problems and to suffer as little interference as possible from the magistrate..$^{98}$ Overburdened magistrates were generally glad to cooperate in this regard and often sent back to the clan cases of disputing clansmen who had sought to bypass its judisdiction. ${ }^{00}$ Some well-organized and effective clans had a hierarchy of authoritative persons to mediate and, when necessary, adjudicate; disputes would be taken from one level to the next higher level until resolved..$^{100}$

Matters did not always follow au orderly path. In every clan there were other persons besides the lineage leaders and elders who had high prestige and considerable leisure and who took pride in settling disputes. If among its niembers a clan boasted "scholar-gentry" (or "official gentry" who were not on active service) ${ }^{101}$ they constituted the local elite and dominated clan and village life. ${ }^{102}$ Where gentry membership did not coincide with clan leadership, gentry clan members may have supplanted the lineage leaders as the effective adjusters of disputes. ${ }^{103}$ Indeed, in areas populated by more than one clan, disputing clansmen may even have turned to gentry who were not members of their clan. ${ }^{104}$ Clan leadership, advanced age and gentry status were not the sole hallmarks of effective mediators. Other persons who combined learning, ability or wealth with a reputation for fairness and wisdom might also be called upon. Formal consideration of a dispute in the clan's ancestral hall was a relatively rare phenomenon. There, discussion was usually led by the clan leaders, the elders and the gentry. After hearing the various views expressed, the head of the clan would suggest a basis for settlement or hand down a judgment. ${ }^{105}$ Most clans permitted a party dissatisfied with

88 Freedian, Lineage Organtzityon in Southeasteren China 115 (1958) Thereinafter cited as FREEDMAN].

99 Id. at 114; HU 57; CH'̈̈, LOCAL GOVERnanent 99.

100 The scholar Liang Ch'i-Ch'ao thus described the situation in his clan: "Whenever a dispute arose between clansmen, an attempt at settlement was made by elderly relatives of the parties. If the disputing parties were not satisfied with the decision, they might appeal to the fen-tz' $u$ [branch ancestral ball] of the fang [branch] to which they belonged. And if they were still unsatisfied, they might then petition the council of elders which was a sort of supreme court for the clan." Quoted in HsLAO, RURAL CHINA 346 (1960) [hereinafter cited as HSIAO]; see also VAA DER SprenkeI 85; HU 58; 2 DOOLITIIE 227.

101 Speaking generally, during the Ch'ing dynasty "scholar-gentry" were persons who had attained the qualifications for bureaucratic appointment by passing certain state examinations but who bad not actually become officials. "Official gentry" were those who had not only qualified for official position but had actually held it. For an excellent detailed study of these terms, see CH'Ü, LOCAL GoverNMENT 168-73.

102 Id. at 168 ; Hsiao 344.

103 FREEDMAN 115.

104 VAN DER SPRENKEI 88.

105 HU 57-59. 
the outcome to take the case before the magistrate, but, for reasons discussed above, relatively few persons actually did. ${ }^{106}$

\section{Disputes Within the Village}

In villages where clan organizations were weak or nonexistent, and in villages composed of more than one clan, disputes could be settled in a variety of ways. If informal mediation by relatives, friends, neighbors or middlemen proved unsuccessful, the parties often resorted to the official village headman. ${ }^{107}$ The village constable also settled many quarrels. ${ }^{108}$ These village officials were usually eager to settle disputes outside the magistrate's yamen, because the magistrate held them responsible for lack of harmony within the village and they knew that he did not want to be bothered with a large volume of petty litigation.

The role of the unofficial village leaders was also extremely important. In every locality certain people of leisure who had no official functions enjoyed great respect and influence and were called upon to restore harmony. In the larger villages these included principally members of the gentry, but also, as in the case of the clans, other persons of high repute. Because the gentry had the greatest prestige in the community, their assistance was often sought $\dot{m}$ disputes between important persons and groups. ${ }^{109}$ If no one in the community had sufficient prestige to settle a dispute, gentry who originally came from the village but who resided elsewhere in the area or leaders of neighboring villages might be called in. ${ }^{110}$ When a controversy occurred between nembers of different villages, the matter was often disposed of by the official heads of the respective villages or by an ad hoc group of gentry or other respected persons from the area. ${ }^{111}$

Disputes were frequently settled at the village or town teahouse which was often found to provide a congenial as well as a neutral and public setting for restoring harnony. After the parties were heard and a reconciliation or decision was reached, the party at fault would often have to pay for all of the "mediating tea" consumed by those present as a minimum condition of settlement. ${ }^{112}$ Or he might have to give a feast for the

106 C. K. Yang, A Chinese Village in Earty Colanunist Transition 97 (1959)

[hereinafter cited as C. K. Y YNG].

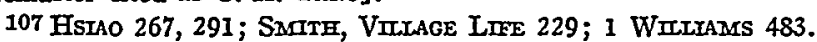

1081 DOOLITILE 306-07.

109 Martin C. YaNG, A Chrnese Viliage 185 (1945) [hereinafter cited as YANG]; Hstao 290-91.

110 YaNG 165; HSIAO 291.

111 Hu 123; Hsiao 309-10; Samte, VinIAge LIFE 280.

112 HsLAo 291; YaNG 196. 
mediators and those involved in the dispute, ${ }^{113}$ or even sponsor a theatrical exhibition for the entertainment of the village at large, ${ }^{114}$ or perform some other act of public service. ${ }^{115}$ Martin C. Yang describes the traditional mediation process in his native village:

The general procedure is as follows: First, the invited or selfappointed village leaders come to the involved parties to find out the real issues at stake, and also to collect opinions from other villagers concerning the background of the matter. Then they evaluate the case according to their past experience and propose a solution. In bringing the two parties to accept the proposal, the peacemakers have to go back and forth until the opponents are willing to meet half- way. Then a formal party is held either in the village or in the market town, to which are invited the mediators, the village leaders, clan heads, and the heads of the two disputing families. The main feature of such a party is a feast. While it is in progress, the talk may concern anything except the conflict. The expenses of the feast will either be equally shared by the disputing parties or borne entirely by one of them. If the controversy is settled in a form of "negotiated peace," that is, if both parties admit their mistakes, the expenses will be equally shared. If the settlement reached shows that only one party was at fault, the expenses are paid by the guilty family. If one party chooses voluntarily, or is forced, to concede to the other . . . it will assume the entire cost. When the heads or representatives of the disputing families are ushered to the feast, they greet each other and exchange a few words. After a hittle while they will ask to be excused and depart. Thus, the conflict is settled. ${ }^{116}$

Like the clans, most villages appear to lave required their residents to exhaust the possibilities of local mediation before taking a dispute to the magistrate. This requirement was enforced by strong social pressure. In the closely-knit context of village life, social pressure largely supplanted legal coercion as a method of settling disputes. As one Westerner familiar with mineteenth-century rural life described the situation: "Ostracism of a complete and oppressive knd is the fate of those who venture to oppose themselves to the public opinion of those about them. Armed with the authority derived from this condition of popular sentiment, the village elders adjust disputes."117 Furthermore, it was not unusual for the magistrate to order would-be litigants to return to their village to have the matter settled by elders, gentry or other important persons. ${ }^{118}$ These mdividuals are said to have strangled millions of incipient

\footnotetext{
113 YANG 165-66.

114 SAMTH, VIrLAGE LIFE 60-61.

115 See HSIAO 281-82.

116 YANG 165-66.

117 DOUGLAS 112-13.

118 Hsiao 291 ; Ch'ن̈, Local GovernMant 323, note 51.
} 
lawsuits. ${ }^{119}$ They mediated all kinds of disputes including those relating to contract, debt, property, torts and divorce as well as other matters that would today be deemed "civil" in nature. ${ }^{120}$ They also intervened in what we would characterize as minor criminal cases. ${ }^{121}$ Mediation was less frequent where crimes of violence, arson, kidnapping and the like were suspected, since in such cases the official leaders often took seriously their duty to report to the magistrate. ${ }^{122}$ Hsiao Kung-ch'uan has written that "cases involving jen-ming (human death) were seldom settled out of court, even where no crime (manslaughter or murder) was committed."123 Yet when such imcidents occurred, those involved sometimes found it to their mutual advantage to hush up the matter by agreeing to an out-ofcourt settlement. This happened, for example, in situations where an unhappy daughter-in-law was driven to suicide by her husband's family. ${ }^{124}$ Sometimes, in order to enrich themselves, yamen underlings would inediate a homicide case rather than report it. Indeed, some have been accused of conspiring with others to trump up false accusations of homicide in order to be able to exploit the opportunity to "mediate."125

\section{Disputes Within the Guild}

Except for the activities of guilds, nineteenth century methods of adjusting disputes in the towns and cities were not substantially different from those employed in the villages. ${ }^{126}$ The resolution of controversies between guild members and the consequent prevention of litigation was one of the main functions of the guilds, which were associations of people who engaged in the same trade or who had come from the same locality to do business in the city. ${ }^{127}$ If a dispute between guild inembers could not be settled informally by one who lad served as a middleman in the transaction or by a mutual friend, the parties could not submit it directly to the magistrate but were usually required by guild regulations to submit it to guild procedures. ${ }^{128}$ Not only would a party who attempted to bypass guild procedures be reprimanded by the guild and perhaps lose access to

119 SMTITH 225.

1201 WrIIIAMs 516.

121 Ibid.

122 HSIAO 292; VAN DER SPRENKEI 122.

128 HsIaO 292.

124 SMITH, VIILAGE LIFE 279-80.

1251 Doolrtile 305-06.

126 See Morse, The Trade and Admonistration of the Cimnese Emopire 74 (1908).

127 See generally Gajarle, Peknng: A Social Survey 163-202 (1921) [hereinafter cited as Ganobire]; VAN DER SpRenkel 90-91.

128 MacGowan, Chinese Guilds or Chambers of Commerce and Trades Unions, in 21 Jouranat of the China Brancer, Royad Astatic Soctety 133, 141 (1886); Gambre 194; VAN DER SPRENKEL 92. 
its valuable services, ${ }^{129}$ but the magistrate would often refer such a case back to the guild for disposition. ${ }^{130}$

In some guilds disputes were settled by the guild officers. In others an ad hoc panel of guild members vas chosen to handle each matter. In small guilds the entire membership might hear the case. ${ }^{131}$ Composition of the authoritative panel sometimes depended on the seriousness of the case. The hearing often took place in the guild hall if there was one, otherwise, in a temple, restaurant or tea-house. After the parties and witnesses had given evidence, the authoritative panel, which operated very informally,,$^{132}$. would do its utmost to arrive at a satisfactory settlement of the dispute by making a decision that would be acceptable to both sides. ${ }^{133} \mathrm{~A}$ decision was not binding unless both parties voluntarily accepted it.

After resort to the guild procedures either side was free to litigate the matter before the magistrate. But because decisions of the guild were backed by powerful social pressures and because of the previously mentioned barriers to- hitigation few cases went to court. ${ }^{134}$ Thus most disputes that went beyond the stage of informal attempts at settlement were disposed of on the basis of a proposal put forth by influential guild members, who were skilled in applying the customs and usages of the group. A familiar basis for settlement was to have a party who had been found to be in the wrong make some gracious gesture toward the group. $\mathrm{He}$ might, for example, have to pay a fine in the form of a contribution of candles for the guild temple or of a concert for the guild ritual or of a feast or theatrical entertaininent for the other party, the members of the panel and some guild members. ${ }^{135}$ This gesture would help to reintegrate the offending party and to reestablish harmony.

\section{CONCLUSION}

Our summary of the late Ch'ing system suggests that, on the eve of China's twentieth-century modernization, the majority of disputes were adjusted within local groups and in most instances by resort to a "flexible and blended procedure of concessions, arrangements [and] compromises"136 that we compendiously call mediation. Closer to the mark may

129 MacGowan, supra note 128 , at 141 . These services included the assistance of the guild in disputes that a member might have with members of other guilds.

130 Van der Sprentei 95 ; Jernigan 219.

131 MacGowan, supra note 128, at 140; Gamble 180.

132 Cf. Gaxible 194-95.

133 MacGowan, supra note 128 , at 141.

134 Gasible 194.

135 MacGowan, supra note 128, at 175, 183-84.

136 ESCARRA 108. 
be A. H. Smith's characteristically colorful description of "the usual Chinese method-a great deal of head knocking and a great many feasts for the injured party."137 In more scholarly terms Mrs. Van der Sprenkel has pointed out that the means employed by these local groups "ranged from completely private mediation at one end of the scale to public adjudication at the other, the one shading into the other almost imperceptibly as public opinion was felt to be more strongly involved."138 Yet, even in many disputes that were resolved by unofficial public adjudication within the local group, the goal was to convince the parties to agree to the imposed solution because of its inherent reasonableness.

A cardinal principle of this system was that the local group generally required the parties to exhaust their remedies within the group before looking to the magistrate for relief. The magistrate, overburdened with the duties of administering the county and of disposing of homicide, theft and other cases in which the government had a vital interest, often cooperated in enforcing this requirement by sending back to the village, clan or guild minor disputes that had not been processed by it, even though this procedure violated the Code. Thus, althougl Ch'ing law, unlike that of Tokugawa Japan, did not nuake extrajudicial mediation a compulsory first step in the process of dispute resolution, in the actual context of Chinese life resort to mediation was frequently no more voluntary than it was in Japan. Generally speaking, the courts could not be said to offer in the first instance a practicable alternative remedy to mediation by the local group. Moreover, once procedures had been exhausted within the group, few disputants were bold enough to challenge the result deemed fair by their group's authoritative members, especially in view of the philosophic and pragmatic reluctance of the Chinese to litigate and the fact that the magistrate often upheld the position of the group's leaders.

From the respective viewpoints of the individual, the local group and the government, how tolerable was this system of resolving most controversies outside the fornal legal structure? For the individual it provided a method of terminating disputes that was socially acceptable in the light of the Confucian ethic and group mores. Altliough the custom of providing food and drink to mediators and of rewarding successful ones was attractive enough to induce self-designated "peace-talkers" occasionally to stir up controversy in the lope of profiting by their intervention, ${ }^{139}$ by and large the extrajudicial process proved to be far less expensive than litigation. Certainly, it was less hazardous and humili-

137 SaItin, VHLtage LIFE 302.

138 VAN DER SPRENKEI 117.

139 Id. at 119. 
ating, and it also disposed of disputes far more quickly and conveniently. The extrajudicial process often allowed both parties considerable opportunity for bargaining through and with third persons whom they were likely to know and respect, whom they could often select, and who might even be familiar with the background of the dispute as well as with local norms and practices. This facilitated a solution with which each party felt he could hive. Occasionally, under social pressures for the restoration of harmony, parties "agreed" to a settlement that failed to do more than gloss over the underlying source of conflict and left tensions that manifested themselves, often violently, at some later date. ${ }^{140}$ Nevertheless, on the whole, this system probably had a greater capacity for bringing about reconciliations and minimizing resentments than did litigation. ${ }^{141}$

In one important respect individuals found the contrast between the extrajudicial and the judicial processes less vivid. Educated, powerful and wealthy persons or families had obvious advantages in settling disputes within the local group as well as before the courts. This often led to bias on the part of the mediators and to an unfair settlement that weaker parties were powerless to prevent. ${ }^{142}$ For example, the resolution of a controversy between persons or families of approximately equal prestige, ability and financial resources often reflected the relevant substantive norms of the community-custom, $l i$, clan, guild or village rules and that part of the government legislation that constituted "living law." But when there was a significant socio-economic disparity between disputants the accommodation arrived at frequently bore little relation to those norms. To some extent considerations of "face" and notions of propriety appear to liave restrained members of the local elite from taking full advantage of their superior position. ${ }^{143}$ Yet Communist writers have not fabricated. out of whole cloth their view that during the Cling dyuasty the wealthy and influential classes manipulated mediation to evade the law and to oppress the toiling masses. It is understandable that, to the extent the Communists acknowledge building upon earlier mediation practices, they do so by referring to the large volume of informal mediation that resolved disputes among the common people.

To the local group a principal virtue of the Ch'ing system was that it fostered social cohesion not only because it tended to minimize hostility but also because it constituted an effective instrument for educating the

140 Id. at 119-20.

141 Tsao, Equity in Chinese Customary Law, in EsSAYs IN JURISPRUdence IN HoNoR of Roscoe Pound 21, 31 (Newman ed. 1962).

142 HSIAO 292; YaNG 242.

143 See Hu, The Chinese Concepts of "Face," 46 Amarucan Anthropologist 45, 47 (1944); YaNg 165-67; FrIEd 209; Van Der Sprenkel 100. Hsu, Amoricans aNd ChINESE 178 (1953); and $c f$. HeNDERson 9. 
group in community values. In persuading and pressuring the parties to agree to a settlement, the mediator was instructing them and all others in attendance about those standards deemed right by the group. ${ }^{144}$ Moreover, this system permitted the group to handle, at least in the first instance, most of those disputes with which it was intimately concerned. This reduced the scope of potential friction between the inagistrate and group leaders and had the more than incidental virtue of sparmg the group the loss of prestige that would have been suffered from revealing its internal quarrels to outsiders. ${ }^{145}$

To the government the system had many advantages. Among these were its contribution to social cohesion, its convemence to disputants, and the political desirability of permitting local people to dispose of relatively unimportant local problems. Moreover, the system relieved the magistrate and his superiors of an enormous burden of hitigation, thereby freeing their energies for more important tasks while saving the government a great deal of expense. It also avoided the necessity of drafting the body of legislation that would have been required to dispose adequately of the range of disputes that were handled by the local groups. In a country as large as China, with its variety of local customs, this would have been a formidable task. ${ }^{146}$ This is, of course, a more positive way of saying that the Chinese emphasis upon mediation significantly emasculated the growth of law througln legislative and judicial processes. The contemporary Western observer, with his appreciation of the contributions that a highly developed legal system can make to the achievement of democratic values, national unity and economic abundance, may regard this as a grave defect of the Ch'ing system, but the Confucianeducated elite of China had an entirely different perspective. ${ }^{147}$

Until the very end of the nineteenth century the policies of both government and society still reflected the status quo-the essential Confucian values and attitudes. Although local groups enjoyed a broad amount of autonomy in settling disputes, they nevertheless rendered the government a distinct service by settling them in accordance with this shared consensus. The government, therefore, had no compelling motivation to intervene. A different situation would arise in the twentietli century, when a succession of Chinese governments no longer shared the traditional

144 See VAN DER SPRENKEI 117. For this reason an authority on Japanese law has characterized this type of mediation as "didactic." HENDERSON 4-5.

145 HU 56; FREEDMIAN 115.

146 VAN DER SPRENKEx 119.

147 One of the many fascinating questions worthy of further research in this field concerns the extent to which the mineteenth-century experience of Chinese businessmen in those areas of China subject to Western law may have led them to develop a greater appreciation of Western law than that attained by the Confucian bureaucracy. See id. at 95 . 
outlook but sought to inject themselves into an active role in the mediation of disputes as part of an overall effort to subject local groups to greater control and thereby transform traditional society.

The present Communist mediation system represents the culmination of these modernization efforts. On the basis of the discussion in this article alone, it would be premature to attempt to compare this contemporary system with that of the past. Our introduction to the subject and summary of the late Ch'ing system does, however, suggest important resonances between past and present. For example, in extrajudicial and judicial practice under both the Ch'ing and present systems, in the words of a Communist slogan, "mediation is the main thing, adjudication is secondary." This reflects the fact that, even though there are vast differences between Confucianism and "the thought of Mao Tse-tung," each of these dommant ideologies is plainly hostile to litigation and places great emphasis upon "criticism-education," self-criticism and "voluntarism." It is also tempting to view the Communists' new local elite of policemen, Party and Youth League inembers, bureaucrats, work supervisors, union activists and mediation committee inembers, and other semi-official persons as successors to the gentry and other prestige figures who settled most of the disputes of village, clan and guild. Comparisons such as these will have to be verified and qualified. Moreover, many related questions will have to be answered. Are the courts more accessible to disputants in the first instance today than they were in the past? Are contemporary techniques of conducting mediation similar to those of the Cli'ing period? Do Communist mediators treat members of the landlord and bourgeois classes more fairly than the toiling masses were treated under previous regimes? How do the standards upon which reconciliations can be based today differ from earlier ones? In the context of twentieth-century Chinese conditions does mediation still have the same advantages for individuals, groups and the government that it formerly had? What are the implications of government and Party control over mediation processes? Other questions should also be asked, but enough has been said to suggest the major lines of future inquiry. 